\title{
THE HEALTH NEEDS OF URBAN BLACK AGED IN CAPE TOWN
}

\author{
E.M. Wolff (R.N., R.M., P. \& N., D.P.H.N.) \\ E. Sophangisa (Social Work Assistant)
}

Department of Comprehensive and Community Medicine

University of Cape Town

\section{OPSOMMING}

Dit is goed bekend dat verstedeliking die omvattende gesinstruktuur verbreek. Dit het veral be'rekking op die bejaardes in 'n Swart gemeenskap. 'n Ondersoek is dus beplan om die gesondheidsbehoeftes van verstedelikte Swart bejaardes te bepaal en vas te stel watter fasiliteite vir hulle versorging nodig is.

Die studie illustreer die feit dat 'n o n'vattende gesondheidsdiens alleen doeltreffend is as daar 'n poging aangewend word om probleme in die gemeenskaaap te identifiseer en om daardie individue dan met die probleme te identifiseer.

$\mathbf{I}_{\mathrm{d}}$ is well known that urbanization leads to a breakdown in the extended family structure; this has particular relevance to the aged in a Black community. A study was therefore designed to assess the health needs of urbanized Black aged and what facilities would be needed for their care.

This study was carried out in the Black residential areas of Cape Town which are situated in the two suburbs of Langa and Guguletu. A cluster sample of dwelling units in each of these suburbs was chosen by random sampling technique. These dwellings were visited and persons over the age of 65 years were asked to complete a questionnaire. The data was coded and transcribed onto marginal punch cards which were then subjected to statistical analysis. One hundred males and 192 females qualified for inclusion in the study.

Eighty-eight percent of the males and $83,9 \%$ of females surveyed were completely independent in that they could attend to their own needs. Five percent of males and $6,3 \%$ of females required some assistance with activities of daily living such as washing, dressing, walking, cooking and were generally confined to their own homes except for escorted outings. Seven percent of males and females were dependent on assistance. The detailed breakdown of symptoms as reported by the respondents is given in Table $I$.
TABLE I

\begin{tabular}{lrrl}
\hline Symptom & \multicolumn{2}{c}{$\%$ Reporting } & Difference \\
& Male & Female & between sexes \\
\hline Dizziness and headache & 53,0 & 71,9 & $\mathrm{p}<0,05$ \\
$\begin{array}{l}\text { Generalized body pains } \\
\text { Malfunctioning or non- }\end{array}$ & 80,7 & 83,0 & Not significant \\
$\quad$ functioning limbs & 36,0 & 36,0 & Not significant \\
$\begin{array}{l}\text { Disability of upper limb } \\
\text { Paralysis or stiffness }\end{array}$ & 25,0 & 7,3 & $\mathrm{p}<0,01$ \\
$\quad$ of lower limb & 25,0 & 29,2 & Not significant \\
Use of mobility aids & 20,0 & 25,5 & Not significant \\
\hline
\end{tabular}

Fifty-four percent of males and $69,8 \%$ of females had consulted a medical facility in the three months preceding the survey $-81,8 \%$ of both sexes consulted a medical facility because of known medical conditions, $16,1 \%$ because of new complaints and $2,1 \%$ because of injury received. The day hospital was the facility of choice for $45,9 \%$ of those seeking medical attention, the hospital was used by $24,0 \%$, the general practitioner by $12,0 \%$ and the remaining $18,2 \%$ consulted a traditional doctor. A large proportion of patients $(42,1 \%)$ were 
able to walk to the facility while the remainder relied on public transport, friends or relatives or transport provided by the hospital. Only $1 \%$ of all the respondents felt that there was a problem in obtaining medical help.

Activities of the respondents were confined mostly to the home except for approximately $20 \%$ who stated that they had a large involvement in church activities. A total of $28 \%$ of respondents complained of feeling lonely for most of the time.

Two percent ( 2 persons) of the male respondents and $4,2 \%$ of female respondents ( 8 persons) were permanently confined to bed. Ten percent of the males (10 persons) and $18 \%$ of females (35 persons) required assistance with everyday activities such as washing, dressing, toilet needs or feeding. Neither those depending upon assistance nor those requiring some assistance were visited regularly by a community health nurse (i.e. health visitor or district nurse).

Major problems of the respondents related to inadequate finance, accommodation, poor health or loneliness.

Although $6,2 \%$ were permanently confined to bed and therefore dependent on assistance, and a further 35 persons $(11,3 \%)$ required assistance with everyday activities, none of them were regularly visited by community health nurses or district nurses. Similar findings were reported in studies of chronic illness in noninstitutionalised persons (Dick) and of health needs of geriatric patients discharged from hospital (Wolff). There was a lack of domiciliary visits by health visitors and district nurses; thus patients were generally not referred to agencies for care in the community, and both patients and their families appeared to resign themselves to the unnecessary difficulties to which they were exposed. This resigned acceptance of fate in households where there is little hope in the present and none for the future has been well documented by Koos; in the words of Lekgetha "Aches and pains are accepted".

The acceptance of aches and pains and discomfort may also prevent hypertensives presenting themselves for treatment. The large numbers of respondents who complained of dizziness and headaches and the reported high incidence of hypertension among Blacks (Seftel) are suggestive of large numbers of aged with hypertensive disease among the Blacks. The underlying causes of malfunctioning and non-functioning limbs of respondents were not investigated. It is possible that a fair number of them were caused by strokes which could have been prevented with adequate treatment. Aciditionally, function could have been improved in many instances with adequate physiotherapy.

The day hospital was used by nearly half of those seeking medical attention, a quarter went to hospital outpatients, $10 \%$ to a general practitioner and the remaining $15 \%$ to a traditional healer. It is interesting to note the large numbers of persons who were able to walk to the medical facility of their choice.

The $1 \%$ of the population who felt that there was a problem in getting medical help possibly illustrates the good situation of the day hospitals and general practi- tioners in the area, i.e. most people found no difficulty in getting medical help during the day. There are no medical services easily accessible in those areas at night. On the other hand the low expectations of the population surveyed might be the reason for so few complaints.

Generalised aches and pains appear high on the list of complaints and this suggests that it might be necessary to provide a screening service to the geriatric population where treatable conditions can be investigated and appropriate management instituted.

Even with minimal resources much can be done to improve the quality of life for the aged. It must be accepted that because the aged do not complain this does not signify that there is no problem; casefindingmethods must be employed so that individuals can be identified. Where community nursing services are unable to cope with any additional workload, a great improvement in the care of the aged can be achieved by supporting and advising those who are caring for them. Youth groups and church groups can be given the names of aged whom they can then visit on a regular basis and thus ease some of their loneliness. Where a suitable venue can be found and perhaps transport arranged for the immobile, a social club can be invaluable for fostering friendships and a feeling of belonging and being wanted.

Demographic data from the 1970 census (Department of Statistics), corrected for population growth, shows that for those legally resident in the Cape there is a need for about 125 beds for the totally dependent aged. This figure is derived from the $7 \%$ of totally dependent Black aged found in this survey. As it is commonly accepted that the de facto Black population is greater than that recorded in the census, this figure represents the minimum number of beds which should be made available.

This study illustrates the fact that for a comprehensive health service to be truly effective an effort must be made to identify problems in the community and to identify those individuals with such problems. Such studies do not require much utilisation of either time or resources.

The field work of this small study could be carried out by a single observer because only an appropriately chosen sample was investigated and not the whole population. The costs involved were minimal and similar studies could easily be replicated without incurring large costs.

ACKNOWLEDGEMENTS:

We would like to thank the Zerilda Steyn Bursary Fund for financial support

REFFRFNCES:

Dick, B., Spencer, I., Watermeyer, G., Bourne, D., Wolff, E., Moyle, G. (1978). Chronic Illmess in Nan-Insiltuilanalised Persons.

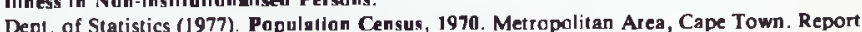
Depl. of Statistics (1977). Government Printer, Pretoria.

02-05-13. Government Printer, Pretoria.

Koos, E.L. (1954) "The Heglth of Regianville". Hafner Co., New York. p.25.
Lekgetha, A. N. Robertson. B. (1978). The Prablems of Lving far our Aged Back Cutuens Lekgetha, A. N., Robertson. B. (1978). The Prablems of

in a Changlng Society. S.A. Nursing Journal, 45 (3), 10.

Sefiel, H. (1973). Medicine and Saclety in South Africa - Same Plain Speaking. Inaugural Lecture, Witwatersiand University Press, Johanneshurg. Wolff, E. (1978). Health Needs af Gerialic Patlents Discharged From Hoapital. S.A. Medical Journal, 54, 116. 